NASA Technical Memorandum 100102

AIAA-87-9257

\title{
Effect of Component Compression on the Initial Performance of an IPV Nickel-Hydrogen Cell
}

(NASA-TH-100102) EFFECT CF CCEECNEAT

CCAPRESSICN CN TEE IHITIAL EEEFCBHASCE OF AN IEV NICKEL-HYDECGEN CELL (NASA) $17 \mathrm{p}$ Avail: NIIS HC AC2/BF A01
$\operatorname{CsCL} 10 \mathrm{C}$
$N 87-24838$

Unclas G3/44 0083760

Randall F. Gahn

Lewis Research Center

Cleveland, Ohio

Prepared for the

22nd Intersociety Energy Conversion Engineering Conference cosponsored by the AIAA, ANS, ASME, SAE, IEEE, ACS, and AIChE Philadelphia, Pennsylvania, August 10-14, 1987 


\author{
EFFECT OF COMPONENT COMPRESSION ON THE INITIAL PERFORMANCE \\ OF AN IPV NICKEL-HYDROGEN CELL \\ Randa 11 F. Gahn \\ Nationa 1 Aeronautics and Space Administration \\ Lewis Research Center \\ Cleveland, Ohio 44135
}

\title{
SUMMARY
}

An experimental method was developed for evaluating the effect of component compression on the charge and discharge voltage characteristics of a 3.5-in.-diameter boller plate cell. A standard boller plate pressure vessel was modified by the addition of a mechanical feedthrough on the bottom of the vessel which permitted different compressions to be applied to the components without disturbing the integrity of the stack. Compression loadings from 0.94 to 27.4 psi were applied by suspending weights from the feedthrough rod. Ce11 voltages were measured for $0.96 \mathrm{C}, 55-\mathrm{min}$ charge and for $1.37 \mathrm{C}, 35-\mathrm{min}$ and $2 \mathrm{C}$, 24-min discharges. An initial change in voltage performance on both charge and discharge as the loading increased was attributed to seating of the components. Subsequent variation of the compression from 2.97 to 27.4 psi caused only minor changes in either the charge or the discharge voltages. Several one month open-circuit voltage stands and 1100 cycles under LEO conditions at the maximum loading have produced no change in performance.

\section{INTRODUCTION}

IPV nickel-hydrogen cells have been developed to a level of confidence that they are being considered for energy storage on the proposed space station. The desired $11 \mathrm{fe}$ of storage batteries for the Space Station and other satellites in low Earth orbit is 5 years. A 5-year life is anticipated if the cel1s are cycled at less than 40 percent depth-of-discharge. An 80 percent depth-of-discharge would reduce the number of batteries required for a mission, but cycle life is then shortened to approximately 1 to 2 years.

The life of an IPV nickel-hydrogen cell appears to be a function of the nickel electrode. One factor limiting the electrode life has been its tendency to swe11. All nickel electrodes have been observed to expand in thickness to varying degrees during charge-discharge cycling in cells. This expansion increases the amount of compression on the components and can cause electrical shorting, separator drying, and mechanical fallure of the cell core (ref. 1). Recent modifications (ref. 2) of the design to include compression washers on each end of the core have allowed the electrode to expand within limited distances and minimized the consequences of the expansion. However, the compression washers do not maintain a specific compression on the components but operate over a specific range of force determined by their design. Thus in an operating cell the pressure on the stack components is changing continuously. Presented in this paper is a study to experimentally evaluate the effect of compression on the cell performance.

The purpose of this study was to measure the initial voltage-current relationships of a $4 \mathrm{~A}-\mathrm{h}, 3.5-\mathrm{in}$.-diameter cell as a function of the compression loading on the components. 


\section{EXPERIMENTAL}

A photograph of the experimental hardware used to determine the effect of component compression on the cell performance is shown in figure 1. A schematic dlagram of the cell assembly and component loading mechanism is shown in figure 2 .

An Air Force boller plate pressure vessel without a wall wick was supported in a vertical position. A 1/8-in. 0-ring sealed male connector was threaded into the bottom of the pressure vesse1. A 1/8-in.-diameter stainless steel rod attached to the compression plate at the top of the stack extended through the 0-ring fitting. A T-shaped weight holder was suspended from the feedthrough rod. Steel weights were laid on the holder to the desired loading.

The cell stack consisted of four unit cells in the back-to-back design. The nickel electrodes were obtained from the Air Force and the hydrogen electrodes from Eagle-Picher. Previous evaluation of nickel electrodes from the same lot indicated they did not have long cycle-life characteristics. This characteristic, however, did not affect their cycle-to-cycle performance reproducibility over a short evaluation period. The nickel electrodes were nominally $0.028 \mathrm{in}$. thick and had a capacity of about $1 \mathrm{~A}-\mathrm{h}$. The hydrogen electrodes were nominally $0.006 \mathrm{in}$. thick. The separator was one layer of beater-treated asbestos approximately $0.010 \mathrm{in.} \mathrm{thick.}$

The cell stack was assembled with dry components. The stack was saturated with 31 percent $\mathrm{KOH}$ by vacuum backfiliting. Excess $\mathrm{KOH}$ was drained and the stack placed in the pressure vessel. The cell assembly rested on plastic spacers in the bottom of the pressure vessel. The $1 / 8-i n$. feedthrough rod went through the center of the stack core and was threaded into the $1 / 8-$ in.thick stainless steel compression plate resting on top of the cell stack. Following evacuation to about 1 torr the vessel was pressurized with approximately 50 psl of hydrogen.

Compression on the components was increased as weights were applied to the holder. The pressure applied by the hydrogen gas on the 1/8-in.-diameter feedthrough rod added about 1-psi loading to the components in the discharged state $\left(\mathrm{H}_{2}=100 \mathrm{ps} 1\right)$ and about 3 psi at full charge $\left(\mathrm{H}_{2}=250 \mathrm{ps} 1\right)$. Component compresstons stated in the report refer to the actual weight applied on the nolder.

\section{RESULTS AND DISCUSSION}

Initially the uncompressed stack loaded at 0.94 psi underwent three formation cycles using a $\mathrm{C} / 10$ to $16 \mathrm{hr}$ charge and a $\mathrm{C} / 4$ discharge. Measured discharge capacity to $0.9 \mathrm{~V}$ was $4.2 \mathrm{~A}-\mathrm{h}$. Cycling parameters for this study were based on a $4 \mathrm{~A}-\mathrm{h}$ capacity stack ( $1 \mathrm{~A}-\mathrm{h} / \mathrm{nickel}$ electrode). Voltage performance and amp-hour capacity for the second and third cycles were identical. The cycling regime to study the effect of increasing compression on the cell performance was begun on the fourth cycle. Four cycles at a specific compression were run on the same day.

The stack was cycled at 80 percent DOD using a 10 percent overcharge. Two cycles were performed with a $0.96 \mathrm{C}, 55-\mathrm{min}$ charge and a $1.37 \mathrm{C}, 35-\mathrm{min}$ 
discharge followed by two cycles at the same charge rate but with a $20,24-m i n$ discharge.

The varlous compression loadings evaluated are given in table $I$ as the total weight applied to the holder and as the pressure per square inch of electrode/separator area.

Performance curves for the $2 \mathrm{C}$ and the $1.37 \mathrm{C}$ discharges of the stack taken during the initial compression are shown in figure 3 and 5 , respectively. At both discharge rates the performance improved with increasing compression. A $30 \mathrm{mV}$ increase was measured at the $2 \mathrm{C}$ rate between the minimum compression of $0.94 \mathrm{ps} 1$ and the maximum compression of 27.4 psi. Voltage curves at 0.94 , $5.68,11.1,19.2$, and 27.4 ps 1 are shown in figure 3 and 117 ustrate the steady voltage increase. The $1.37 \mathrm{C}$ discharge voltages improved about $20 \mathrm{mV}$ as the compression was increased from 2.97 to $27.4 \mathrm{ps} 1$.

During the initial compression process, loading was increased in 20-1b increments until the 19.2 psi compression was reached. At this point the compression was reduced in one step to $2.97 \mathrm{psi}$. After the standard four cycle regime was performed, the compression was increased in one step to 27.4 psi.

As can be seen in figure 5 the performance for the 2.97 psi compression (cycle 43) following the 19.2 pst loading was about $12 \mathrm{mV}$ higher than the init1al performance at 2.97 psi (cycle 15). Increasing the compression to 27.4 psi improved the discharge voltage by an additional $5 \mathrm{mV}$ over the 19.2 psi loading. It is also significant that with a decrease in compression (19.2 to 2.97 ps1) the stack performance decreased only $5 \mathrm{mV}$.

The $0.96 \mathrm{C}$ charge curves for the $2 \mathrm{C}$ and $1.37 \mathrm{C}$ rate discharges are shown in figure 4 and 6 , respectively. An unexpected decrease in charging performance, 1.e., higher voltage, was observed as the compression was increased from 0.94 to $27.4 \mathrm{ps} 1$. In figure 4 the charge voltage reached a maximum value at 19.2 psi. The charge curve at 27.4 psi loadings was essentially the same as at 19.2 psi. The maximum difference between the 0.94 and 27.4 ps 1 loadings was about $25 \mathrm{mV}$. The charge performance given in figure 6 for the $1.37 \mathrm{C}$ discharge shows the voltage increase from the 2.97 to 19.2 psi cycle. However, when the compression was then reduced to 2.97 psi the charge curve did not change. Increasing the compression from 2.97 to $27.4 \mathrm{ps} 1$ in one step also had no effect on the charge performance.

Following testing at the maximum loading the stack was removed from the pressure vessel and vacuum backfilled with 31 percent $\mathrm{KOH}$ to resaturate the asbestos separators. Although the components were loosened during saturation, their positioning on the core was unchanged.

The stack was returned to the pressure vessel. The ampere hour capacity for two cycles at $\mathrm{c} / 10$ to $16 \mathrm{hr}$ charge and $\mathrm{c} / 4$ to $0.9 \mathrm{~V}$ discharge was $4.58 \mathrm{~A}-\mathrm{h}$ compared to the initial capactity of $4.20 \mathrm{~A}-\mathrm{h}$.

The standard cycling regime was repeated with increasing compressions of $0.94,5.68,11.1,16.5,21.9$, and 27.4 psi. Voltage curves for the $1.37 \mathrm{C}$ discharge cycles at $5.68,16.5$, and $27.4 \mathrm{ps} 1$ are shown in figure 7 . An improvement in performance of about $10 \mathrm{mV}$ was observed as the compression was increased from 5.68 to $27.4 \mathrm{ps} 1$. However, the performance appears to 
stabilize at the 16.5 psi loading. The charge performance results are given in figure 8 . Only curves at 5.68 and 27.4 psi are shown because no difference was observed at any of the loadings.

The cell was also evaluated for the effects of short term loading at the maximum compression. Standard cycling after 36 and 78 days on open-circuit resulted in a voltage increase of about $10 \mathrm{mV}$ for both the discharge and charge. This change was not considered significant but is a typical variation in performance during an open-circuit stand.

Following the open-circult stand a LEO $(0.96 \mathrm{C}, 55-\mathrm{min}$ charge and $1.37 \mathrm{C}$, 35-min discharge) cycling period was initiated at maximum loading. After 1100 charge/discharge cycles some changes occurred in the overall performance when compared to the initial voltage characteristics. This was expected and was not significant or a factor of the compression. Charge voltages increased about $10 \mathrm{mV}$. Discharge voltages decreased about $30 \mathrm{mV}$ but after undergoing the standard characterization cycling regime the voltages were within $10 \mathrm{mV}$ of the voltages before the extended cycling.

The effect of component compression on the performance was determined again following the 1100 continuous cycles. Three compressions, $0.94,11.1$, and 27.4 psi were evaluated using the standard characterization cycles. Discharge results are shown in figure 9. Two $1.37 \mathrm{C}$ discharge cycles were run at 0.94 ps 1 to establish performance reproductbility. Voltage characteristics for the discharges were nearly identical at this loading. Single cycles were then run at 11.1 and 27.4 psi. Voltages at 27.4 psi were about $10 \mathrm{mV}$ greater than at $0.94 \mathrm{psi}$. The $11.1 \mathrm{ps} 1 \mathrm{cycle}$ was between the other two.

Charging performance at $0.96 \mathrm{C}$ for the three compressions is shown in figure 10. Except for some voltage differences early in the charges, the performance was unaffected by the changes in compression.

\section{CONCLUDING REMARKS}

Throughout this study the discharge performance of the cell improved as the compression on the components increased. A voltage increase of about $30 \mathrm{mV}$ was observed during initial compression of the stack from 0.94 to $27.4 \mathrm{ps} 1$. After 1100 LEO cycles the voltage increase was only about $10 \mathrm{mV}$. An unexpected increase in charging voltages was observed when the compression was increased. During the initial compression from 0.94 to 27.4 psi, voltages increased about $25 \mathrm{mV}$. However, after the stack had been compressed to 19.2 psi further changes (both higher and lower) in the component compression did not affect the charging voltages.

Although only one cell was evaluated in this study and the overall compression range was limited, a feasible method was developed for further investigations.

\section{REFERENCES}

1. Muller, V.C., "Faflure Analysis of Nickel-Hydrogen Cell Subjected to Simulated Low Earth Orbit Cycling." The 1983 Goddard Space Flight Center Battery Workshop, NASA CP-2331, 1984, pp. 523-538. 
2. Smithrick, J.J., Manzo, M.A., Gonzalez-Sanabria, 0., "Advanced Designs for IPV Nicke1-Hydrogen Cells." Paper 849555, Proceedings of the 19th IECEC, Vo1. 1, pp. 631-634, August 19-24, 1984, San Francisco, California.

TABLE I - COMPRESSION LOADINGS

APPLIED TO THE 3.5-1n.-DIAMETER,

7.38-in. 2 CELL

\begin{tabular}{|c|c|}
\hline $\begin{array}{c}\text { Applied weight, } \\
\text { Tb }\end{array}$ & $\begin{array}{c}\text { Component compression, } \\
\text { psi }\end{array}$ \\
\hline 6.9 & 0.94 \\
11.9 & 1.61 \\
21.9 & 2.97 \\
41.9 & 5.68 \\
61.9 & 8.39 \\
81.9 & 11.10 \\
101.9 & 13.80 \\
121.9 & 16.50 \\
141.9 & 19.20 \\
201.9 & 27.40 \\
\hline
\end{tabular}




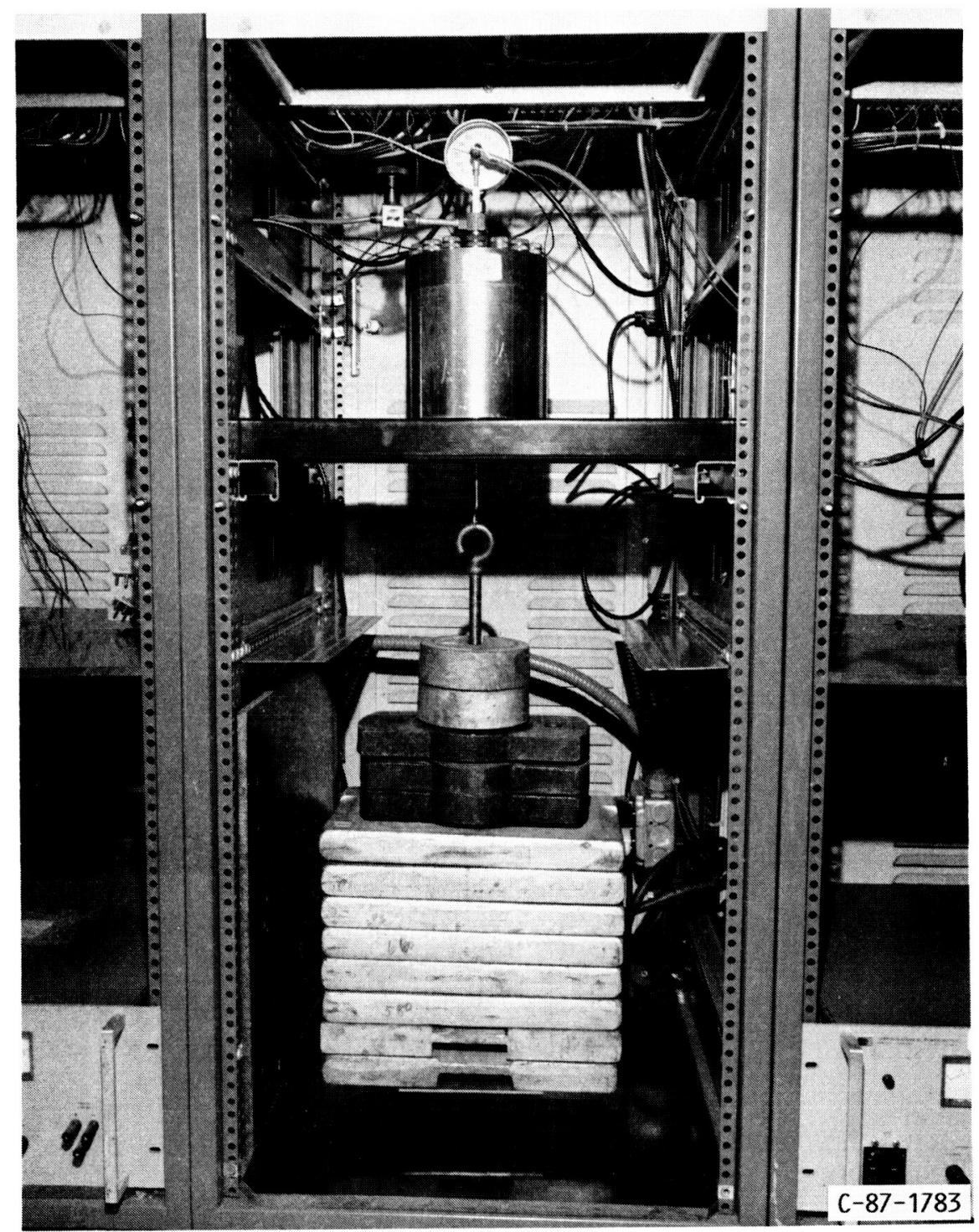

FIGURE 1. - IPV NICKEL-HYDROGEN CELL COMPRESSION-TEST FACILITY.

ORGWAL PBOE TS
OF POOR QUALTTY 


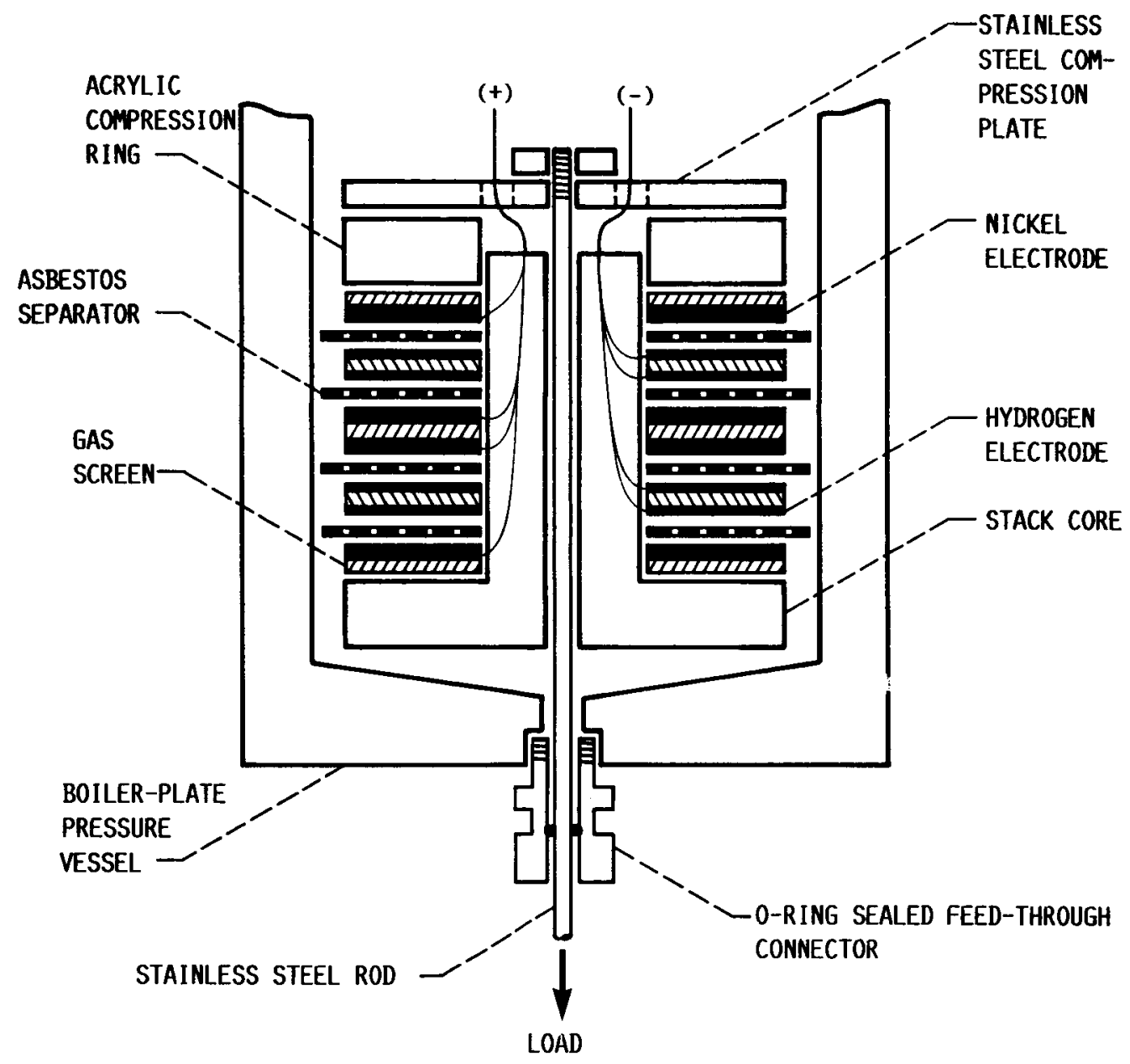

FIGURE 2. - CELL ASSEMBLY AND COMPONENT LOADING MECHANISM. 


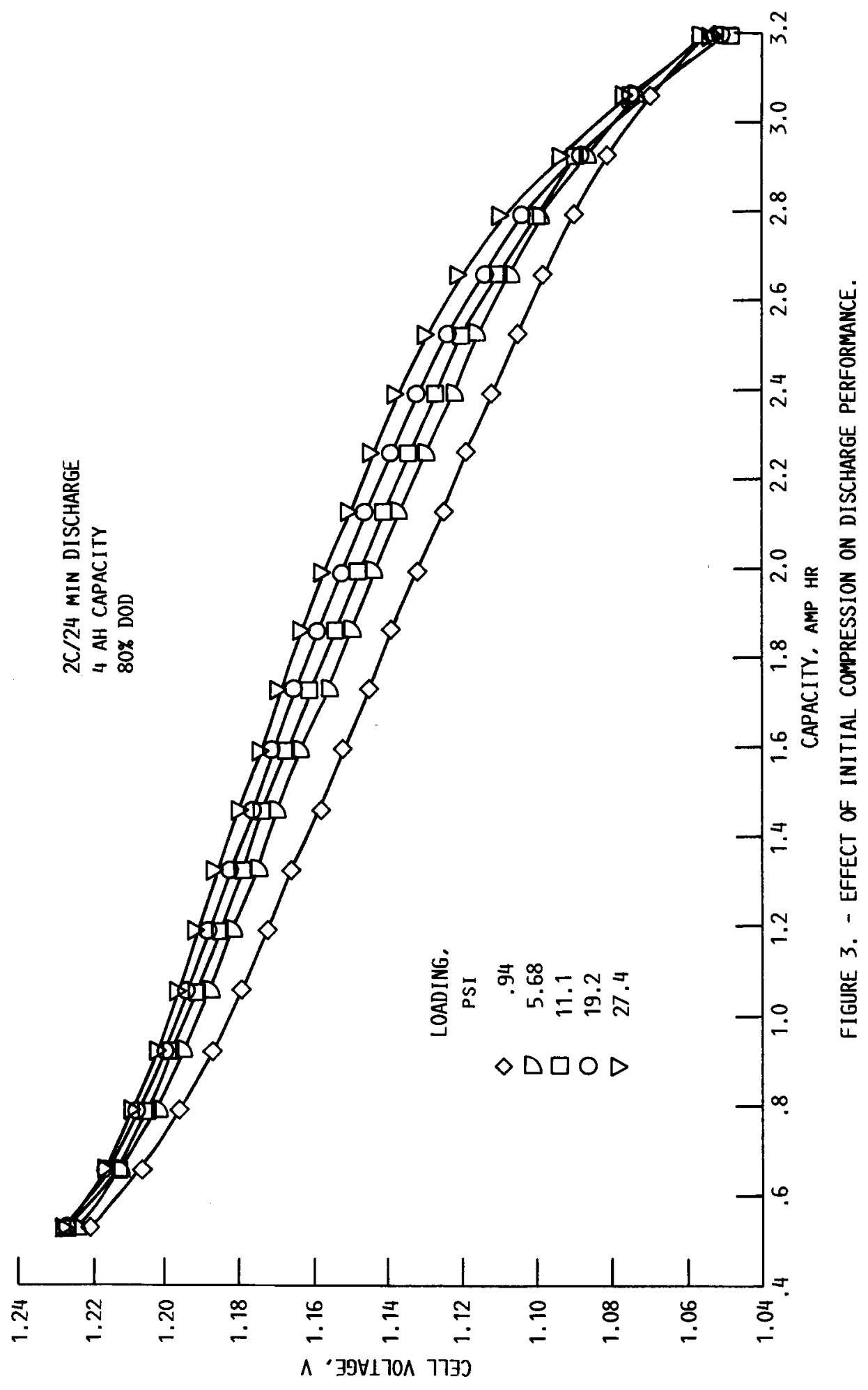




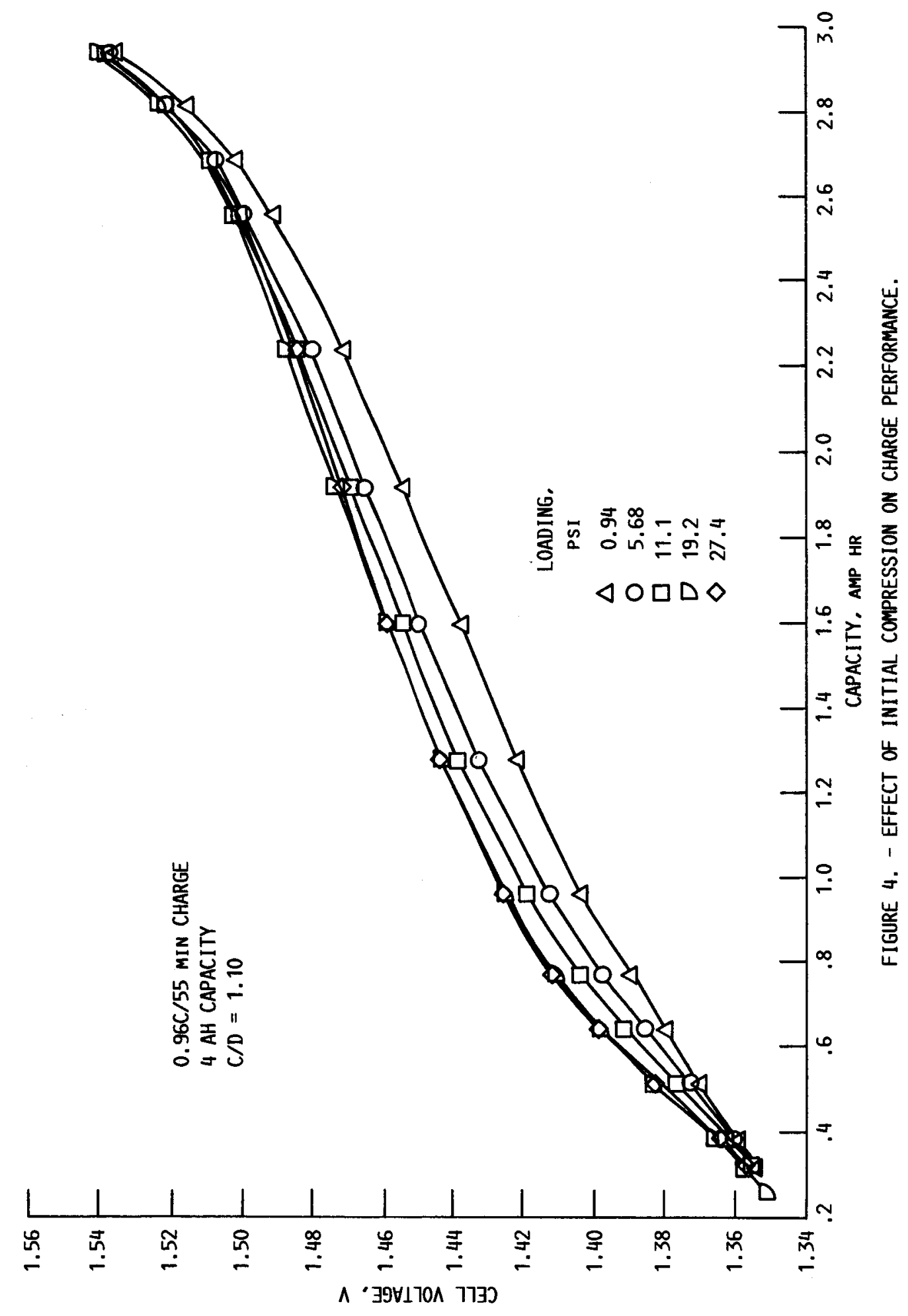




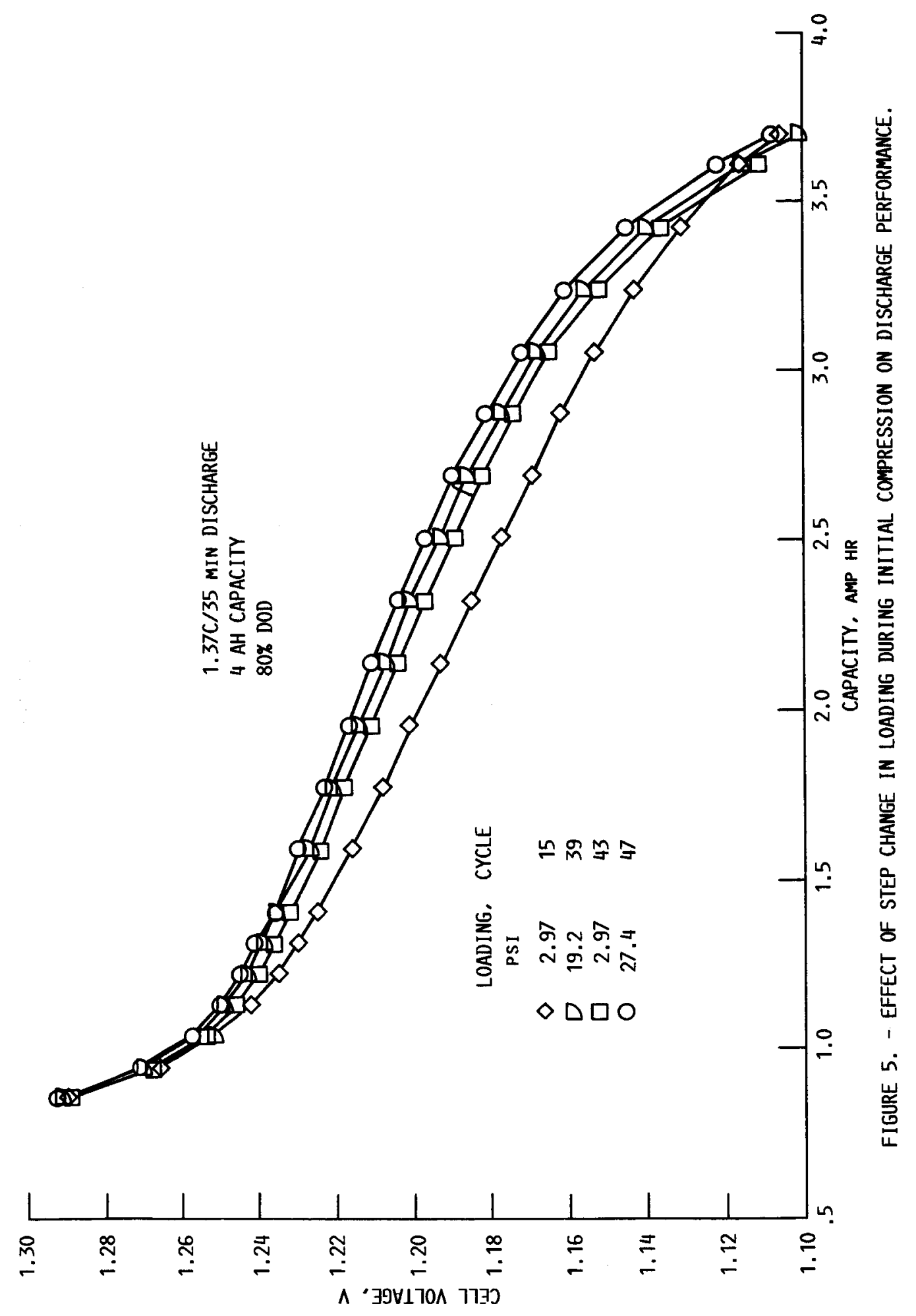




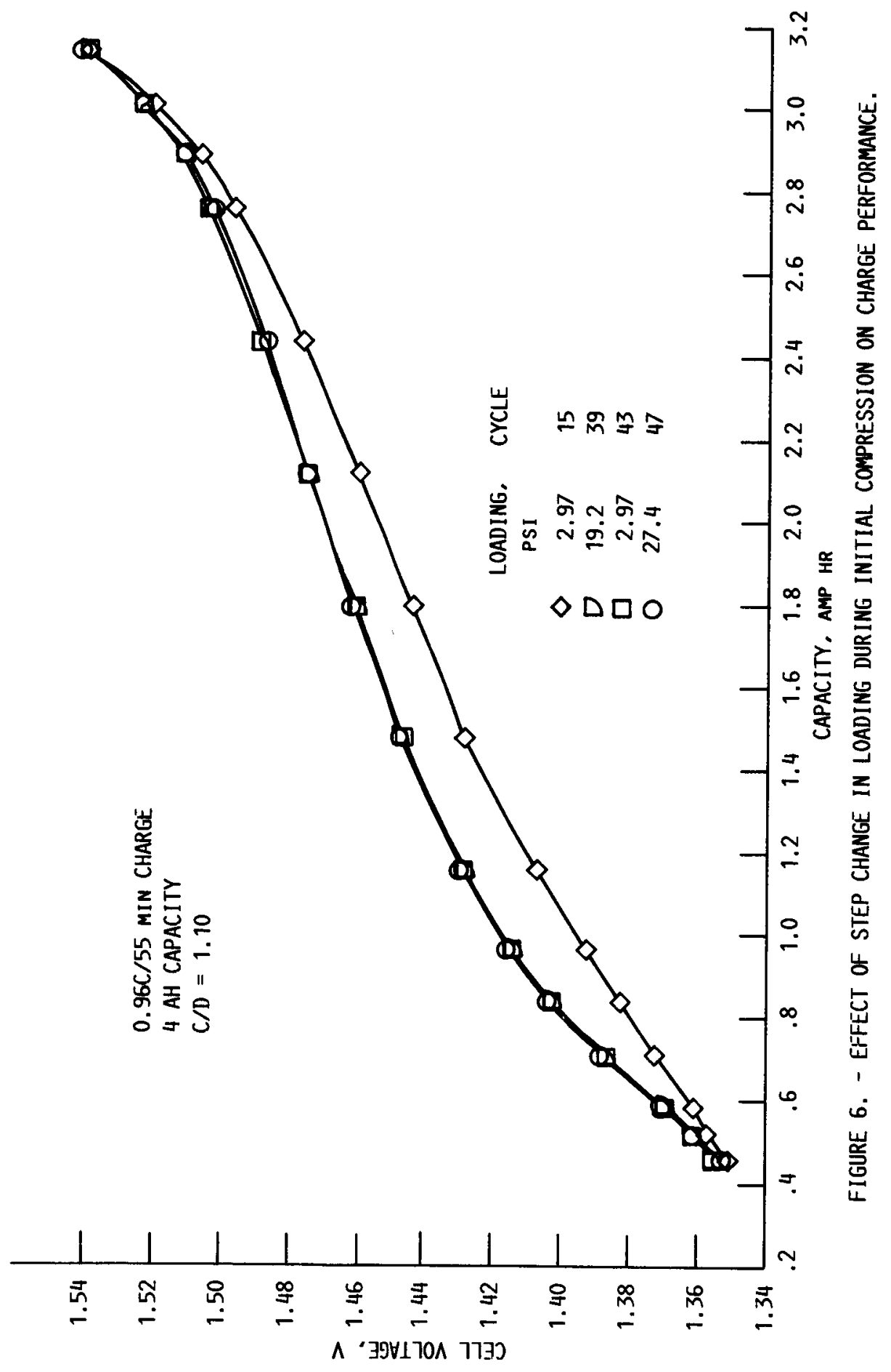




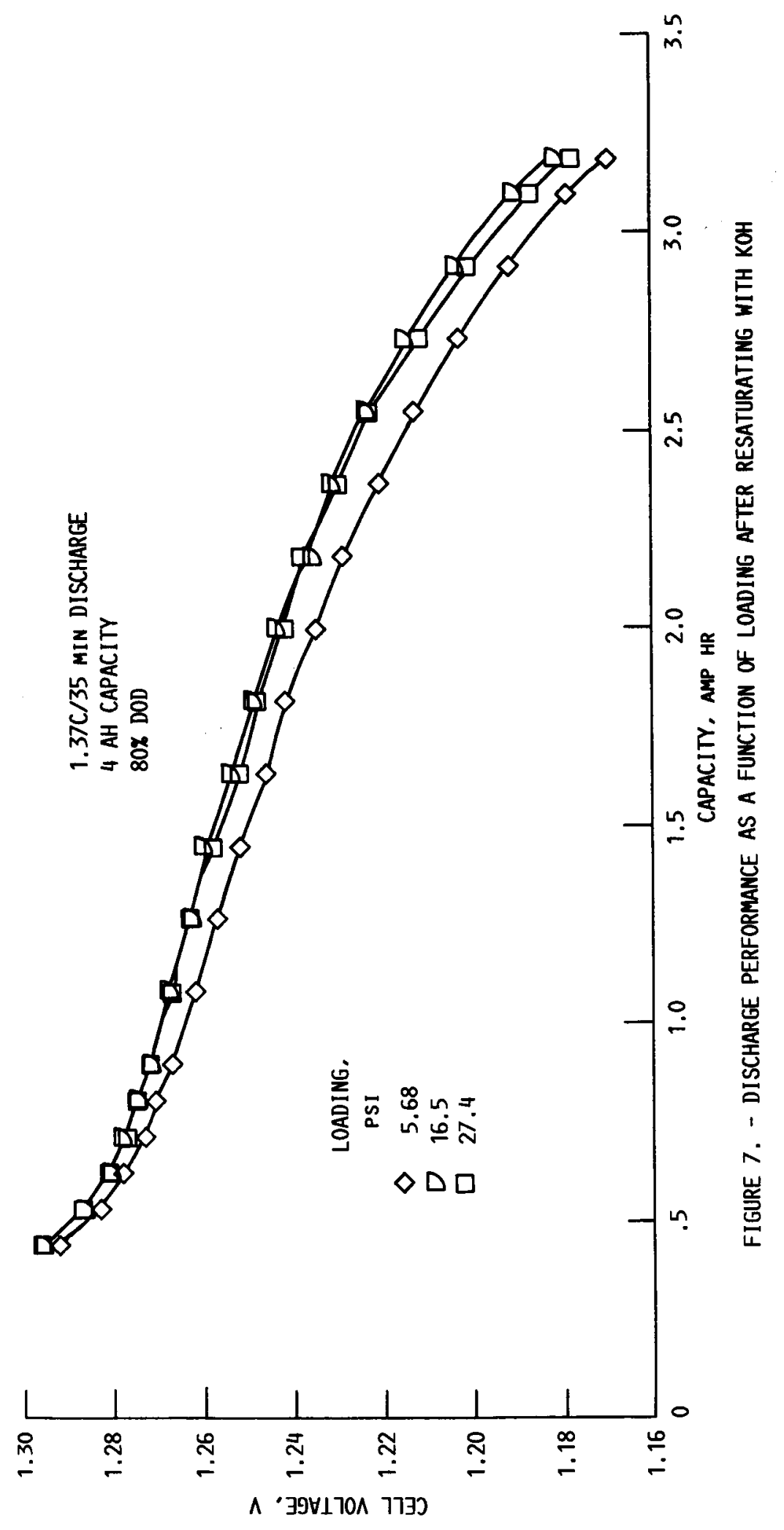




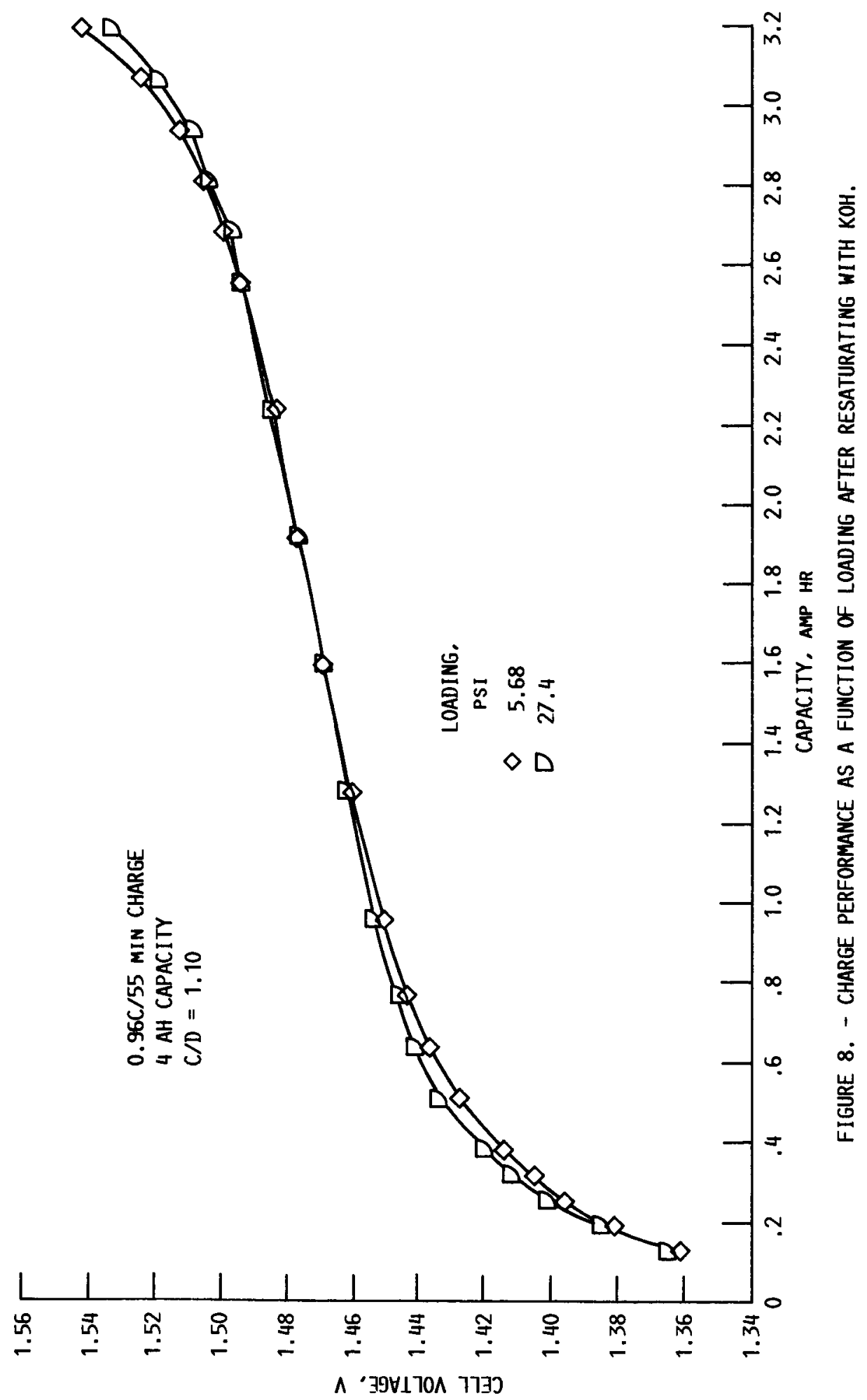




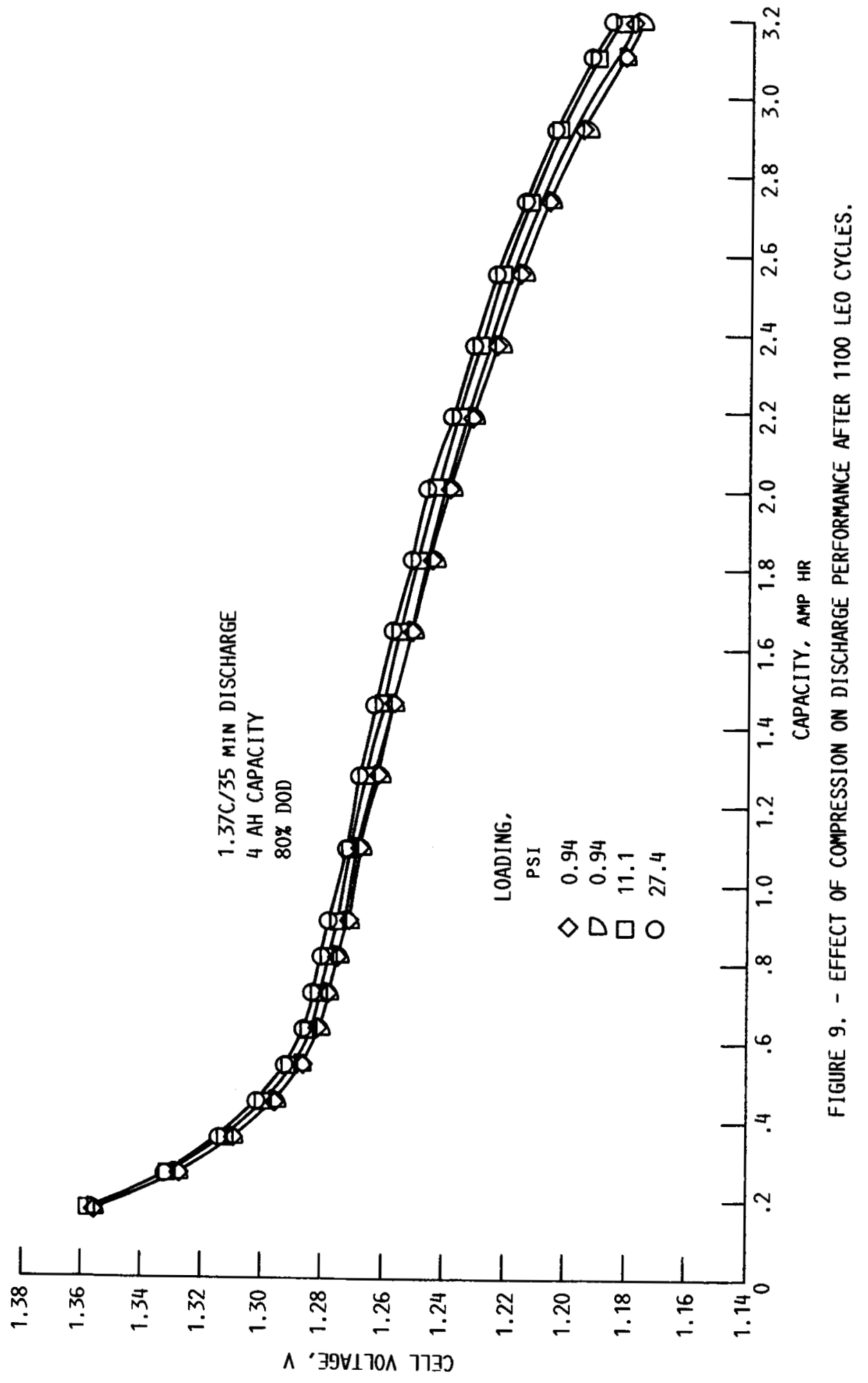




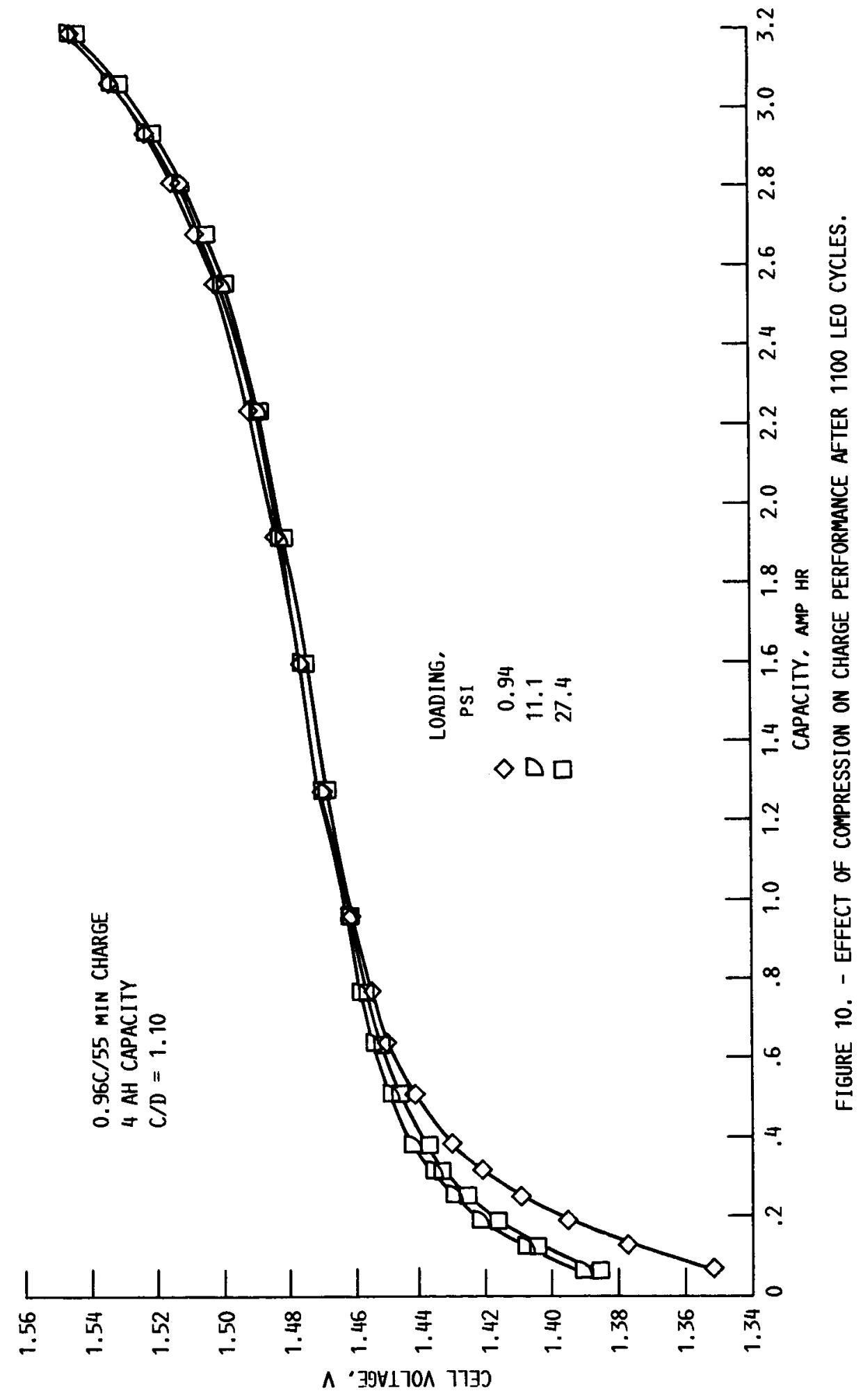




\begin{tabular}{|c|c|c|c|}
\hline \multicolumn{4}{|l|}{ WS } \\
\hline $\begin{array}{l}\text { NASA TM-100102 } \\
\text { AIAA-87-9257 }\end{array}$ & 2. Government Accession No. & \multicolumn{2}{|c|}{ 3. Recipient's Catalog No. } \\
\hline 4. Tille and Sublitle & & \multicolumn{2}{|l|}{ 5. Report Date } \\
\hline \multicolumn{2}{|c|}{$\begin{array}{l}\text { Effect of Component Compression on the Initial } \\
\text { Performance of an IPV Nickel-Hydorgen Cell }\end{array}$} & \multicolumn{2}{|c|}{$\begin{array}{l}\text { 6. Performing Organization Code } \\
506-41-21\end{array}$} \\
\hline \multirow[t]{2}{*}{ Randall F. Gahn } & & \multicolumn{2}{|c|}{$\begin{array}{l}\text { 8. Performing Organization Report No. } \\
\text { E-3590 }\end{array}$} \\
\hline & & \multicolumn{2}{|l|}{ 10. Work Unit No. } \\
\hline \multicolumn{2}{|l|}{ 9. Performing Organization Name and Address } & \multirow{2}{*}{\multicolumn{2}{|c|}{ 11. Contract or Grant No. }} \\
\hline \multicolumn{2}{|c|}{$\begin{array}{l}\text { National Aeronautics and Space Administration } \\
\text { Lewts Research Center } \\
\text { Cleveland, Ohio } 44135\end{array}$} & & \\
\hline \multicolumn{2}{|l|}{ 12. Sponsoring Agency Name and Address } & \multicolumn{2}{|c|}{$\begin{array}{l}\text { 13. Type of Report and Period Covered } \\
\text { Technical Memorandum }\end{array}$} \\
\hline \multicolumn{2}{|c|}{$\begin{array}{l}\text { National Aeronautics and Space Administration } \\
\text { Washington, D.C. } 20546\end{array}$} & \multicolumn{2}{|c|}{ 14. Sponsoring Agency Code } \\
\hline \multicolumn{4}{|c|}{$\begin{array}{l}\text { Prepared for the } 22 \text { nd Intersoclety Energy Conversion Engineering Conference } \\
\text { cosponsored by the AIAA, ANS, ASME, SAE, IEEE, ACS, AIChE, Philadelphia, } \\
\text { Pennsylvania, August } 10-14,1987 \text {. }\end{array}$} \\
\hline \multicolumn{4}{|c|}{$\begin{array}{l}\text { An experimental method was developed for evaluating the effect of component com- } \\
\text { pression on the charge and discharge voltage characteristics of a } 3-1 / 2 \text { in. diam- } \\
\text { eter bofler plate cell. A standard boiler plate pressure vessel was modified by } \\
\text { the addition of a mechanical feedthrough on the bottom of the vessel which per- } \\
\text { mitted different compressions to be applied to the components without disturbing } \\
\text { the integrity of the stack. Compression loadings from } 0.94 \text { to } 27.4 \text { psi were } \\
\text { applied by suspending weights from the feedthrough rod. Cell voltages were meas- } \\
\text { ured for } 0.96-C, 55-\text { min charge and for } 1.37-C, 35 \text {-min and } 2-c \text {, } 24 \text {-min discharges. } \\
\text { An initial change in voltage performance on both charge and discharge as the } \\
\text { loading increased was attributed to seating of the components. Subsequent vari- } \\
\text { ation of the compression from } 2.97 \text { to } 27.4 \text { psi caused only minor changes in } \\
\text { either the charge or the discharge voltages. Several one month open-circuit } \\
\text { voltage stands and } 1100 \text { cycles under LE0 conditions at the maximum loading have } \\
\text { produced no change in performance. }\end{array}$} \\
\hline $\begin{array}{l}\text { 17. Key Words (Suggested by Author(s)) } \\
\text { Batteries } \\
\text { Nickel-hydrogen batterie } \\
\text { Energy storage }\end{array}$ & $\begin{array}{l}\text { 18. Dis } \\
\text { Unc } \\
\text { STI }\end{array}$ & $\begin{array}{l}\text { ent } \\
\text { ry } 44\end{array}$ & \\
\hline $\begin{array}{l}\text { 19. Security Classif. (of this report) } \\
\text { Unc lassif ted }\end{array}$ & $\begin{array}{l}\text { 20. Security Classit. (of this page) } \\
\text { Unc las if Ied }\end{array}$ & 21. No of pages & $\begin{array}{r}\text { 22. Price" } \\
\mathrm{AO2}\end{array}$ \\
\hline
\end{tabular}

